\title{
The Relationship between Extrinsic vs. Intrinsic Motivation and Strategic Use of Language of Iranian Intermediate EFL Learners
}

\author{
Zeinab Moradi Khazaie \\ University of Isfahan, Isfahan, Iran \\ Zahra Mesbah \\ Sharif University of Technology, Tehran, Iran
}

\begin{abstract}
This study aims to identify the learning orientations and language learning strategies of the students, to determine whether there are any significant differences in the motivational orientations and language learning strategies preferences between male and female learners, and investigate whether there is a relationship between students' motivational orientations and strategy preferences. A total of 206 intermediate level students who studied in English in private language institutes were asked to complete two questionnaires. One was used to identify students' motivational orientations and the other was used to identify students' learning strategies. Statistical analyses demonstrated that most frequent type of motivation was extrinsic motivation-identified regulation; and the most frequent used strategy was social strategy; and that both types of motivations, namely extrinsic motivation and intrinsic one revealed positive correlation with six language learning strategies. However, amotivation demonstrated negative and significant correlation with all the six language learning strategies. Finally, the findings indicated significant difference between male and female students in terms of employing language learning strategies. Female students used more language strategies and they applied cognitive strategies, meta-cognitive strategies, and social strategies more often in comparison with male learners while male students used more compensation strategies. Based on the results, the study suggested that teachers should attempt to detect learners' language motivation and their choice of language learning strategies so as to provide them with more effective learning materials and opportunities which may enhance their language learning.
\end{abstract}

Index Terms - language learning strategy, intrinsic motivation, extrinsic motivation, individual difference variables

\section{INTRODUCTION}

Learning a foreign language is one of the most prominent needs and it has become a crucial component in people's lives. Studying at an English medium university or living in a foreign country are among numerous reasons which makes people all over the world try to learn it as a second language.

Several scholars in the field have been attempting to detect some teaching methods, techniques, and instructional materials that promote better language instruction (Rubin, 1975; Stern, 1975; Chamot \& Kupper, 1989, Ramsey, 1980). However, despite all these efforts there has been an increasing concern that learners have not had progress as much as it was expected. Since there exist considerable individual differences in language learning such as gender, age, motivation, attitude, aptitude, culture, etc., what can be productive for one might be counterproductive for another. Therefore, according to Reiss (1983), none of the methods and techniques has proved that they can work all the time, in all classes, with all students. As a result, it might be appropriate to consider Grenfell and Harris' (1999) statement that "Methodology alone can never be a solution to language learning. Rather it is an aid and suggestion" (p. 10).

Having this point in mind some other researchers (e.g., Deci \& Ryan, 2000; Gardner, 1985, Dornyei, 2000; Littelwood, 1996) shifted the focus from the language teaching methodology to the language learner and individual difference variables that influence language learning. This change of the main point has led to an increase in the number of studies carried out with respect to the learner characteristics and foreign or second language learning. Language Learning Strategies (LLS) have been one of the most crucial points researchers have focused on. However, they investigated them along with some other variables such as gender, achievement, motivation, attitude, aptitude, learning styles, and so on in order to show whether there is any relationship between the LLS choice and these kinds of variables.

Oxford (1989) suggested a synthesis of the studies conducted with respect to the LLS and the variables that affect strategy choice. She focused on the results of studies carried out with regard to LLS choice and language being learned, duration, degree of awareness, age, and gender, affective variables such as attitudes, motivational level, personality characteristics, and general personality type. 
According to Willing (1988), classroom practice can lead to the development of good and appropriate learning strategies. He defined it in this way:

a) Exploration of strategies which learners are already making use of, which derive from their previous education and their own cognitive individuality; this exploration can be done through questionnaire and discussion.

b) Exploration of the relation between individual learning style and the person's existing strategies. (p. 172)

Motivational orientation of the students can be reflected in their choice of language learning strategies. Braten and Olaussen (1998) conducted their study on the Norwegian to examine the relationship between motivation and language learning strategies. They found intelligent as an important in learning factor that affect both motivation and language learning strategies use. They also found high correlation between student's motivational belief and their choice of language learning strategies.

Pintrich and Garcia (1991) posited that motivated students tend to use more learning strategies compared to less motivated one. Besides, they suggested that intrinsically motivated students employed more cognitive strategies such as elaboration and organization.

Fleming and Walls (1998) stated use of metacognitive strategies contribute to the learners' self direction, autonomy, and independency. In fact, those learners who adopt metacognitive strategies more are more autonomous learners that are more responsible for their own learning through monitoring their learning process.

Oxford and Nyikos (1989) also asserted formal practice strategies are the most frequent strategies among the learners while functional practice strategies which are related to the authentic use of language are the least frequent one. Furthermore, they claimed that motivation can influence students' choice of language strategies. They also assumed that those students, who are more motivated, use more learning strategies in comparison with less motivated students.

Pong (2002) found that intrinsic motivation had closer relationship with language achievement and influence the choice of strategies more than extrinsic motivation. It was also found that more intrinsically motivated students had tendency to use cognitive and meta-cognitive strategies while extrinsically motivated one prefer to use affective strategies more.

On the other hand, McIntosh and Noels (2004) reported significant as well as positive correlation among selfdetermination, motivation and the kind of language learning strategies.

Bacon and Finnemann (1990) concluded motivation plays an important role in the choice of language learning strategies. They probed the correlation between motivation, attitude, and language learning strategies. More specifically, integratively oriented students were reported to use more global and synthetic strategies while avoiding analytic strategies.

Chang and Huang (1999) in their study on the Taiwanese students found that there was significant correlation between motivation and language learning strategies. Further, they suggested more intrinsically motivated students use more cognitive and metacognitive strategies while extrinsic motivation highly correlated with cognitive and affective strategies.

Chang (2005) also found that more motivated students used more learning strategies and both extrinsically and intrinsically motivated students tend to use evaluating and planning strategies more than the other strategies.

In addition to motivation, gender is another variable that was taken into account in the present study while determining students' language learning strategies. A wide variety of studies have already been conducted with respect to the effect of gender on students' choice of language learning strategies. In the following paragraphs some of these studies are considered.

Kaylani (1996) found significant differences between male and female students in terms of strategy use. The results of his study with 225 participants using MANOVA analysis showed that gender exerts an effect on the students' choice of language learning strategies. Female students used memory, cognitive, compensation, and affective strategies more than male students while with regard to metacognitive and social strategies, no significant difference was found between two genders.

Oxford and Nyikos (1989) also found significant difference between male and female students with regard to language learning strategies. They reported two kinds of learning strategies, namely general study strategy and formal rule based strategies were used more by female students. They attributed this result to the females' desire for good grades, a need for social approval, their verbal superiority to males, and females' greater willingness to conform to norms.

Ehrman and Oxford (1989) also conducted their study on adult language learners and they found females students preferred to use general study strategies, functional practice strategies, strategies for searching for and communicating meaning, and self-management strategies more than male students.

In another study carried out by Green and Oxford (1995), the findings demonstrated that female students used higher levels of strategy more than male students. It was reported that female students used some strategies including using flashcards to remember words, reviewing English lessons often, connecting words and locations, skimming and reading carefully, seeking L1 words similar to L2 words, making summaries of information, etc., more than male students. However, male students used watching TV programs and video movies in English more often than females. 
Tabanlioglu (2003) found no significant difference between male and female students in terms of choosing language learning strategies. He found that both male and female students prefer to use cognitive strategies more than other kinds of strategies.

Chang, Liu, and Lee (2007) also found significant difference between female and male students in terms of cognitive strategies, meta-cognitive strategies, social strategies and overall strategies with regard to gender. In fact, male learners presented less frequently in using overall strategy than did female learners. They found no significant difference between male and female students with regard to memory strategies, compensation strategies, and affective strategies by gender. Finally, they reported that female students used cognitive, meta-cognitive, and social strategies more than male students.

In a separate study, Lee (2003) also found significant difference between Taiwanese male and female students with respect to the range of language learning strategies. Male students were more strategic users than female ones.

To recognize and teach according to each student's strengths and preferences allows for the maximum potential in learning to occur. The presents study is an attempt to broaden teachers' understanding of students' strategies use and enhance students' learning. Furthermore, it helps students with some preferences of employing effective learning strategies to enhance their learning.

Since insufficient study has ever examined this important issue in Iran, the present study aimed to investigate the language learning strategies the students prefer to use, and to investigate whether there exists any relationship between language learning strategies and individual difference variables such as motivation and gender to fill the gap in the literature in the related field of second language learning.

\section{Methodology}

The present study was designed to examine language learning strategies used by Iranian EFL language learners. Motivational orientations and gender differences in language learning strategies were also taken into account.

\section{A. Participants}

A total number of 206 students in Iran participated in the present study. All the participants were intermediate students based on the results of Nelson proficiency test (200A). Of the 206 recruited students, 115 were female (55.8\%) and 91 were male students (44.2). Their age ranged from 18 to 25 years old.

\section{B. Instruments}

Questionnaires were employed for the purpose of data collection on students' language learning strategies, motivational orientation, and their background information.

\section{Language Learning Strategies Inventory}

Strategy inventory for language learning developed by Oxford (1990) was utilized to identify learners' language learning strategies. The second version of the questionnaire, which is used with learners of English as a foreign language, was administered. It includes 50 items with Cronbach reliability of .94. It consists of six subsections and each section represents one of the six categories of language learning strategies. The 50 statements in the inventory follow the general format and students responded based on 5 point Likert scale ranging from 1 "Never or almost never true of me" to 5 "Always or almost always true of me".

\section{Motivational Orientation Inventory}

The instrument employed for collecting data on students' motivational orientations was a questionnaire, language learning orientation scale, including 21items. The questionnaire was developed by Noels, Pelletier, Clement and Vallerand (2000) based on the claims and criteria of Vallerand, Pelletier, Blais, Briere, Senecal, and Valliers (1992). There are seven sub-scales in the inventory including amotivation (items 1-3), external regulation (items4-6), introjected regulation (items 7-9), identified regulation (items10-12), intrinsic motivation-accomplish (items13-15), intrinsic motivation-knowledge (items16-18) and intrinsic motivation-stimulation (items 19-21). It is based on a 5-point Likert scale ranging from, "strongly agree" to "strongly disagree" and the first three items on the questionnaire were negative statements and interpreted reversely.

In the present study amotivation was measured through three items, intrinsic motivation was measured through nine items in terms of three indicators, including motivation-knowledge, intrinsic motivation-accomplishment, and intrinsic motivation stimulation. Extrinsic motivation was measured through nine items in terms of three components such as external regulation, introjected regulation, and identified regulation. 
Amotivation

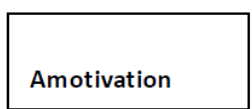

Extrinsic Motivation

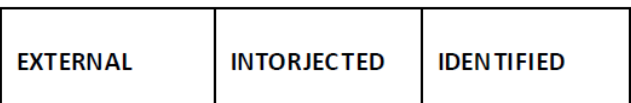

Intrinsic motivation

Knowledge

Accomplishment

Stimulation

Figure 2.1: The self-Determination Continuum and the Different Types of Motivations (Deci \& Ryan,1985;Vallerand et al., 1992)

\section{Procedure}

Quantitative approach was followed with regard to the process of data gathering and analyses. The data were gathered in two main stages. The first stage focused on the completion and collection of the questionnaires related to motivational orientations.

In the second stage, language learning strategies inventory including 50 items was administered to respondents to choose their preferred langue learning strategies. The participants were also informed about the purpose of the study to make their best contribution. Furthermore, the researcher provided the consent form which presented detailed information about the research and assured confidentiality. Then, the questionnaires, which were numbered to provide confidentiality, were randomly administered to 206 language learners who were learning English as a foreign language at intermediate level. Students who participated in the study were required to choose statement ranging from 1 (strongly disagree) to 5(strongly agree) on the motivational orientation scale. They were also asked to choose statement from 1 (never) to 5 (always) on the language learning strategies inventory.

\section{RESULTS}

In this section, statistical information based on the analyses of students' responses to the Motivational orientations questionnaire and the Strategy Inventory for Language Learning was explained. Furthermore, the relationship between students' motivational orientations and language learning strategies was examined. Finally, the effect of gender on students' choice of language learning strategies and strategy usage was reported.

Research Question 1: Which language learning strategy is the most commonly used strategy and which one is shunned?

As able 3.1 illustrates, the mean of frequency of overall strategy use was 3.30, which was approximately at a medium degree (with a range from 1 to 5). According to the results of Table 3.1, the most frequently used strategy was social strategy $(M=3.75)$, and followed by cognitive strategy (3.55), meta-cognitive strategy $(M=3.46)$, memory strategy $(\mathrm{M}=3.14)$, compensation strategies $(\mathrm{M}=3.02)$, and affective strategies $(\mathrm{M}=2.88)$. As Table 3.1 displays, there was not a big difference among the frequency of each strategy that Iranian learners report using.

TABLE 3.1:

SUMMARY OF DESCRIPTIVE STATISTICS FOR LANGUAGE LEARNING STRATEGY USE

\begin{tabular}{l|l|l}
\hline Strategy use & Mean & Standard Deviation \\
\hline Memory strategy & 3.14 & .148 \\
\hline Cognitive strategy & 3.55 & .250 \\
\hline Metacognitive strategy & 3.46 & .271 \\
\hline Affective strategy & 2.88 & .272 \\
\hline Social strategy & 3.75 & .321 \\
\hline Compensation strategy & 3.02 & .176 \\
\hline Overall Strategy Use & 3.30 & .239 \\
\hline
\end{tabular}

It was indicated form the results that students tended to use social strategy most frequently in comparison with other language learning strategies. Besides, affective strategy was found to be the least commonly used strategy among Iranian students. The mean and standard deviation for each item on learning strategies were shown in Table 3.2. 
TABLE 3.2:

DESCRIPTIVE STATISTICS FOR EACH STRATEGY ITEMS

\begin{tabular}{|c|c|c|}
\hline Strategy Items & Mean & SD \\
\hline 1. I think of the relationship between what I already know and new things I learn in English. & 2.76 & 1.29 \\
\hline 2. I use new English words in a sentence so I can remember them. & 3.63 & 1.33 \\
\hline $\begin{array}{l}\text { 3. I connect the sound of a new English word and an image or picture of the new word to help me } \\
\text { remember the word. }\end{array}$ & 2.59 & 1.11 \\
\hline $\begin{array}{l}\text { 4. I remember a new English word by making a mental picture of a situation in which the word } \\
\text { might be used. }\end{array}$ & 3.50 & 1.19 \\
\hline 5. I use rhymes to remember new English words. & 3.13 & 1.16 \\
\hline 6. I use flashcards to remember new English words. & 3.46 & 1.27 \\
\hline 7. I physically act out English words. & 2.58 & 1.26 \\
\hline 8. I review English lessons often. & 3.81 & .87 \\
\hline $\begin{array}{l}\text { 9. I remember new English words or phrases by remembering their location on the page, on } \\
\text { the board, or on a street sign. }\end{array}$ & 3.0 & 1.37 \\
\hline 10. I say or write new English words several times. & 2.76 & 1.29 \\
\hline 11. I try to talk like native speakers. & 3.70 & 1.38 \\
\hline 12. I practice the sounds of English. & 3.17 & 1.29 \\
\hline 13. I use the English words I know in different ways. & 3.39 & 1.00 \\
\hline 14. I start conversations in English. & 4.00 & 1.48 \\
\hline 15. I watch English language TV shows spoken in English or go to movies spoken in English. & 4.50 & .68 \\
\hline 16. I read for pleasure in English. & 3.02 & .92 \\
\hline 17. I write notes, messages, letters, or reports in English. & 3.32 & 1.44 \\
\hline $\begin{array}{l}\text { 18. I first skim an English passage (read over the passage quickly) then go back and read } \\
\text { carefully. }\end{array}$ & 4.04 & .78 \\
\hline 19. I look for words in my own language that are similar to new words in English. & 3.67 & 1.20 \\
\hline 20. I try to find patterns in English. & 4.00 & 1.22 \\
\hline 21. I find the meaning of an English word by dividing it into parts that I understand. & 3.15 & 1.41 \\
\hline 22. I try not to translate word-for-word. & 3.05 & 1.34 \\
\hline 23. I make summaries of information that I hear or read in English. & 3.99 & 1.10 \\
\hline 24. To understand unfamiliar English words, I make guesses. & 2.86 & .86 \\
\hline 25. When I cannot think of a word during a conversation in English, I use gestures. & 3.24 & 1.20 \\
\hline 26. I make up new words if I do not know the right ones in English. & 2.84 & 1.17 \\
\hline 27. I read English without looking up every new word. & 2.14 & 1.41 \\
\hline 28. I try to guess what the other person will say next in English. & 3.50 & 1.21 \\
\hline 29. If I cannot think of an English word, I use a word or phrase that means the same thing. & 3.58 & 1.16 \\
\hline 30. I try to find as many ways as I can to use my English. & 3.19 & 1.46 \\
\hline 31. I notice my English mistakes and use that information to help me do better. & 3.39 & 1.09 \\
\hline 32. I pay attention when someone is speaking English. & 3.93 & 1.21 \\
\hline 33. I try to find out how to be a better learner of English. & 2.53 & 1.15 \\
\hline 34. I plan my schedule so I will have enough time to study English. & 4.00 & .94 \\
\hline 35. I look for people I can talk to in English. & 3.80 & 1.52 \\
\hline 36. I look for opportunities to read as much as possible in English. & 3.45 & 1.61 \\
\hline 37. I have clear goals for improving my English skills. & 3.24 & .82 \\
\hline 38. I think about my progress in learning English. & 3.57 & 1.05 \\
\hline 39. I try to relax whenever I feel afraid of using English. & 2.77 & 0.83 \\
\hline 40. I encourage myself to speak English even when I am afraid of making a mistake. & 3.21 & 1.27 \\
\hline 41. I give myself a reward or treat when I do well in English. & 3.06 & 1.12 \\
\hline 42. I notice if I am tense or nervous when I am studying or using English. & 2.53 & 1.15 \\
\hline 43. I write down my feelings in a language learning diary. & 2.99 & 1.57 \\
\hline 44. I talk to someone else about how I feel when I am learning English. & 2.75 & 1.47 \\
\hline $\begin{array}{l}\text { 45. If I do not understand something in English, I ask the other person to slow down or to say it } \\
\text { again. }\end{array}$ & 2.77 & .83 \\
\hline 46. I ask English speakers to correct me when I talk. & 3.35 & 1.36 \\
\hline 47. I practice English with other students. & 3.86 & .64 \\
\hline 48. I ask for help from English speakers. & 4.19 & .95 \\
\hline 49. I ask questions in English. & 3.63 & 1.07 \\
\hline 50. I try to learn about the culture of the English speakers. & 4.71 & .45 \\
\hline
\end{tabular}

RQ2: Are Iranian learners more intrinsically motivated or extrinsically motivated?

The motivation questionnaire was composed of three main components, namely amotivation, intrinsic motivation (in terms of three sub-scales, including intrinsic motivation-knowledge, intrinsic motivation-accomplishment, and intrinsic motivation-stimulation), and extrinsic motivation (including three sub-components, namely external regulation, identified motivation, and introjected regulation). Descriptive statistics for each motivation item is presented in Table 4.3. 
TABLE 3.3.

DESCRIPTIVE STATISTICS FOR EACH MOTIVATION ITEM

\begin{tabular}{l|l|l}
\hline Variables & Mean & SD \\
\hline $\begin{array}{l}\text { 1.I cannot come to see why I study a second language, and frankly, I } \\
\text { don't give a damn }\end{array}$ & 3.34 & .86 \\
\hline $\begin{array}{l}\text { 2. Honestly, I don't know, I truly have the impression } \\
\text { of wasting my time in studying a second language. }\end{array}$ & 2.82 & 1.39 \\
\hline $\begin{array}{l}\text { 3. I don't know; I can't come to understand what I am doing studying a } \\
\text { second language. }\end{array}$ & 3.12 & 1.26 \\
\hline 4. Because I have the impression that it is expected of me. & 2.94 & 1.07 \\
\hline 5. In order to get a more prestigious job later on. & 3.53 & 1.49 \\
\hline $\begin{array}{l}\text { 6. In order to have a better salary later on. } \\
\text { 7. To show myself that I am a good citizen because I can speak a } \\
\text { second language. }\end{array}$ & 2.52 & .71 \\
\hline $\begin{array}{l}\text { 8. Because I would feel ashamed if I couldn't speak to my friends from } \\
\text { the second language community in their native tongue. }\end{array}$ & 2.86 \\
\hline 9. Because I would feel guilty if I didn't know a second language. & 2.57 \\
\hline $\begin{array}{l}\text { 10. Because I choose to be the kind of person who can speak more than } \\
\text { one language. }\end{array}$ & 3.51 & 1.36 \\
\hline 11. Because I think it is good for my personal development. & 0.87 \\
\hline $\begin{array}{l}\text { 12. Because I choose to be the kind of person who can speak a } \\
\text { second language. }\end{array}$ & 2.84 & 1.11 \\
\hline $\begin{array}{l}\text { 13. For the pleasure that I experience in knowing more about the } \\
\text { literature of the second language group. }\end{array}$ & 2.76 & 1.13 \\
\hline 14. For the satisfied feeling I get in finding out new things. & 2.81 & 1.29 \\
\hline $\begin{array}{l}\text { 15. Because I enjoy the feeling of acquiring knowledge about the second } \\
\text { language community and their way of life. }\end{array}$ & 2.74 \\
\hline $\begin{array}{l}\text { 16. For the pleasure I experience when surpassing myself in my second } \\
\text { language studies. }\end{array}$ & 2.73 & 1.11 \\
\hline $\begin{array}{l}\text { 17. For the enjoyment I experience when I grasp a difficult construct in } \\
\text { the second language. }\end{array}$ & 2.79 & 1.11 \\
\hline $\begin{array}{l}\text { 18. For the satisfaction I feel when I am in the process of accomplishing } \\
\text { difficult exercises in the second language. }\end{array}$ & 2.75 \\
\hline $\begin{array}{l}\text { 19. For the "high" I feel when hearing foreign languages spoken. } \\
\text { 20. For the "high" feeling that I experience while speaking in the second } \\
\text { language. }\end{array}$ & 2.7 .28 & 1.28 \\
\hline $\begin{array}{l}\text { 21. For the pleasure I get from hearing the second language spoken by } \\
\text { native second language speakers. }\end{array}$ & 3.03 & 1.11 \\
\hline
\end{tabular}

Furthermore, Cronbach's alphas of the scales, the means and standard deviations, and the intercorrelation among them were estimated (Table 4.4). The pattern of intercorrelations is similar to Noels, Pelletier, Clement, and Vallerand (2000)'s results that reported a simplex pattern and more positive and higher correlations among adjacent scales. Another similarity lied in the fact that that identified regulation reveals a higher negative correlation with amotivation than the intrinsic motivation subscales.

TABLE 3.4:

MOTIVATION SUBSCALE MEANS, STANDARD DEVIATIONS, INTER-CORRELATIONS, AND CRONBACH'S ALPHA INDICES OF INTERNAL CONSISTENCY

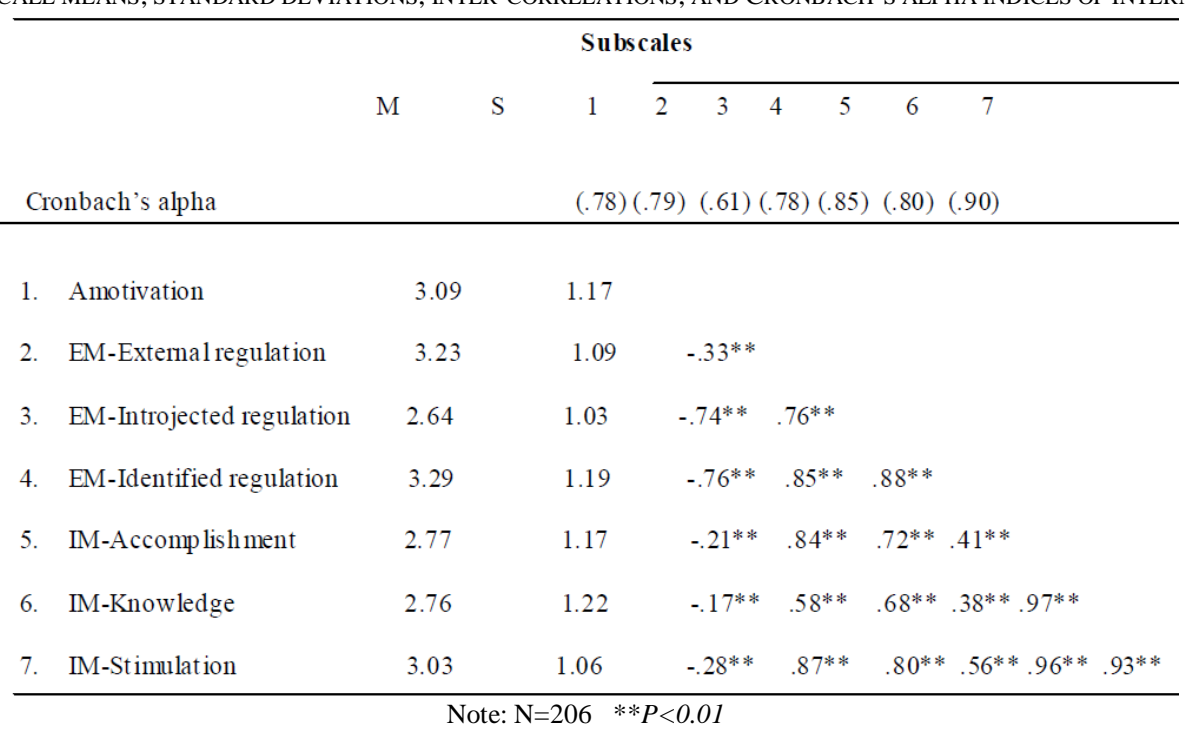

As table 4.4 illustrates, among the seven motivation subscale, the mean of identified regulation as one of the subscale of extrinsic motivation was the highest $(M=3.29)$, followed by extrinsic motivation-external regulation $(M=3.23)$, 
Amotivation ( $\mathrm{M}=3.09)$, intrinsic motivation-stimulation $(\mathrm{M}=3.03)$, intrinsic motivation accomplishment $(\mathrm{M}=2.77)$, intrinsic motivation- Knowledge ( $M=2.76)$, and finally extrinsic motivation- introjected regulation $(M=2.64)$.

The results showed that students were more extrinsically motivated, implying that most of the students learned English for external reasons instead of intrinsic ones.

RQ3: Is there any relationship between gender and frequency of strategy use?

T-test of equality of means was run to examine the relationships between gender differences and the use of language learning strategies. The results of this t-test analysis are illustrated in Table 4.5.

Based on the findings, significant differences were reported between male and female learners concerning overall strategy use. The obtained value for $t$ is $2.52, p=.012$ (see Table 4.5). This value is higher than the critical value of 1.96 for $t$ with 204 degrees of freedom at .05 level of significance. In fact, female students employed more language learning strategies than male students.

Male learners revealed less frequently in using overall strategy than female ones and the means of frequency for male and female learners in overall strategy were 3.19 and 3.31, respectively. According to the results of six subcategories of language learning strategies, significant differences did not exist in the use of memory strategies $(t=1.80, P=.07>.05)$ and affective strategies by gender $(\mathrm{t}=-.28, \mathrm{p}=.77>.05)$. However, significant differences existed in the use of cognitive strategies $\left(\mathrm{t}=-4.37^{*}, \mathrm{p}=.000<.05\right)$, meta-cognitive strategies $\left(\mathrm{t}=3.65^{*}, \mathrm{p}=.000<.05\right)$, compensation strategy $\left(-.208^{*}\right.$, $\mathrm{p}=.03<.05)$, and social strategies $\left(\mathrm{t}=3.08^{*}, \mathrm{p}=.002<.05\right)$. The means of frequency of male learners in using cognitive strategies, meta-cognitive strategies, compensation strategies, and social strategies were $(\mathrm{M}=3.47, \mathrm{M}=3.10, \mathrm{M}=3.17$, and $M=3.63$ ), respectively; the means of frequency of female learners in using cognitive strategies, meta-cognitive strategies, compensation strategies, and social strategies were $(\mathrm{M}=3.66, \mathrm{M}=3.40, \mathrm{M}=2.99$, and $\mathrm{M}=3.84)$, respectively. Consequently, female learners employed more cognitive strategies, meta-cognitive strategies, and social strategies than male learners. On the other hand, male students employed compensation strategies more than their female counterparts.

TABLE 3.5:

SUMMARY OF VARIATION IN LANGUAGE LEARNING STRATEGY USE BY GENDER

\begin{tabular}{|c|c|c|c|c|c|c|}
\hline Strategies & Gender & $\mathrm{N}$ & Mean & SD & $t$ & $P$ \\
\hline Memory strategy & $\begin{array}{l}\text { Female } \\
\text { Male }\end{array}$ & $\begin{array}{l}115 \\
91\end{array}$ & $\begin{array}{l}3.20 \\
3.00 \\
\end{array}$ & $\begin{array}{l}1.21 \\
1.13 \\
\end{array}$ & 1.80 & .07 \\
\hline Cognitive strategy & $\begin{array}{l}\text { Female } \\
\text { Male }\end{array}$ & $\begin{array}{l}115 \\
91\end{array}$ & $\begin{array}{l}3.66 \\
3.47 \\
\end{array}$ & $\begin{array}{l}0.71 \\
0.69 \\
\end{array}$ & $-.37 *$ & .000 \\
\hline Compensation Strategy & $\begin{array}{l}\text { Female } \\
\text { Male }\end{array}$ & $\begin{array}{l}115 \\
91 \\
\end{array}$ & $\begin{array}{l}2.99 \\
3.17\end{array}$ & $\begin{array}{l}1.19 \\
1.22\end{array}$ & $-.208 *$ & .03 \\
\hline Meta-Cognitive Strategy & $\begin{array}{l}\text { Female } \\
\text { Male }\end{array}$ & $\begin{array}{l}115 \\
91 \\
\end{array}$ & $\begin{array}{l}3.40 \\
3.10 \\
\end{array}$ & $\begin{array}{l}1.08 \\
1.18 \\
\end{array}$ & $3.65^{*}$ & .000 \\
\hline Affective strategy & $\begin{array}{l}\text { Female } \\
\text { Male }\end{array}$ & $\begin{array}{l}115 \\
91\end{array}$ & $\begin{array}{l}2.77 \\
2.80\end{array}$ & $\begin{array}{l}1.22 \\
1.17\end{array}$ & -.28 & .773 \\
\hline Social Strategy & $\begin{array}{l}\text { Female } \\
\text { Male }\end{array}$ & $\begin{array}{l}115 \\
91\end{array}$ & $\begin{array}{l}3.84 \\
3.63\end{array}$ & $\begin{array}{l}.90 \\
.83\end{array}$ & $3.08^{*}$ & .002 \\
\hline Overall Strategy Use & $\begin{array}{l}\text { Female } \\
\text { Male }\end{array}$ & $\begin{array}{l}115 \\
91\end{array}$ & $\begin{array}{l}3.31 \\
3.19\end{array}$ & $\begin{array}{l}1.05 \\
1.03\end{array}$ & $2.52^{*}$ & .012 \\
\hline
\end{tabular}

RQ 4: Is there any relationship between motivational orientations (Extrinsic vs. Intrinsic) and the learners' choice of language learning strategies?

Pearson product moment correlation analysis was run to survey the relationship between motivation and language learning strategies. The results were summarized in Table 4.6.

Results indicated that Amotivation was negatively and significantly correlated to all six language learning strategies, in the sequence of affective strategy ( $r=-.60)$, met-cognitive $(r=-.54)$, cognitive $(r=.-44)$, memory $(r=.-43)$, compensation $(\mathrm{r}=.-36)$, and social $(\mathrm{r}=-.26)$ at the .01 level.

Furthermore, the findings shed light on the fact that three indicators of extrinsic motivation, including external regulation, identified, and introjected regulation showed positively and significantly correlation with all six types of language learning strategies. External regulation correlated with language learning strategies in the sequence of affective strategy $(\mathrm{r}=.79)$, meta-cognitive strategy $(\mathrm{r}=.56)$, social strategy $(\mathrm{r}=.51)$, cognitive strategy $(\mathrm{r}=.45)$, memory strategy $(\mathrm{r}=.33)$, and compensation strategy $(\mathrm{r}=.30)$.

Same with external motivation, identified motivation showed positively and significantly correlation with all six language learning strategies in the following sequence: affective strategy $(\mathrm{r}=.82)$, meta-cognitive strategy $(\mathrm{r}=.72)$, cognitive strategy $(\mathrm{r}=.56)$, memory strategy $(\mathrm{r}=.54)$, compensation strategy $(\mathrm{r}=.51)$, and social strategy $(\mathrm{r}=.38)$ at the .01 level.

Introjected motivation also showed positive and significant correlation with all six strategies in the sequence of affective strategy ( $\mathrm{r}=.93)$, meta-cognitive strategy ( $\mathrm{r}=.72)$, cognitive strategy ( $\mathrm{r}=.55)$, memory strategy (.48), compensation $(\mathrm{r}=.43)$, and social strategy $(\mathrm{r}=.42)$ at the .01 level.

Finally, three sub-scales of intrinsic motivation showed high and significant correlation with all six language learning strategies. Intrinsic motivation-accomplishment showed correlation in this order: affective strategy $(\mathrm{r}=.78)$, meta- 
cognitive $(\mathrm{r}=.47)$, social strategy $(\mathrm{r}=.42)$, cognitive strategy $(\mathrm{r}=.36)$, memory strategy $(\mathrm{r}=.24)$, and compensation strategy $(\mathrm{r}=.20)$ at the .01 level.

Intrinsic motivation-knowledge revealed significant correlation with language learning strategies in this way: affective strategy $(\mathrm{r}=.75)$, meta-cognitive $(\mathrm{r}=.45)$, social strategy $(\mathrm{r}=.44)$, cognitive strategy $(\mathrm{r}=.35)$, memory strategy $(\mathrm{r}=.23)$, and compensation strategy $(\mathrm{r}=.20)$ at the .01 level.

The last component of the intrinsic motivation, namely stimulation also revealed positive and significant correlation with all six language learning strategies in the sequence of affective strategy $(\mathrm{r}=.85)$, meta-cognitive strategy $(\mathrm{r}=.57)$, social strategy $(\mathrm{r}=.43)$, cognitive strategy $(\mathrm{r}=.41)$, compensation strategy $(\mathrm{r}=.31)$, and memory strategy $(\mathrm{r}=.29)$ at the .01 level.

Moreover the results showed that both intrinsic and extrinsic motivations were highly correlated with affective and met-cognitive strategies. It was also revealed that learners with stronger motivation tended to use more language learning strategies. In the present study female learners were found to be more motivated and they employed more language learning strategies in comparison with their male counterparts.

TABLE 3.6:

CORRELATION BETWEEN MOTIVATION AND LANGUAGE LEARNING STRATEGIES

\begin{tabular}{|c|c|c|c|c|c|c|c|}
\hline & Amotivation & External & Identified & Introjected & Accomplishment & Knowledge & stimulation \\
\hline Memory &.$-43 * *$ & $.33 * *$ & $.54 * *$ & $.48 * *$ & $.24 * *$ & $.23 * *$ & $.29 * *$ \\
\hline Cognitive & $-.44 * *$ & $.45^{* *}$ & $.56^{* * *}$ & $.55^{* * *}$ & $.36^{* * *}$ & $.35 * *$ & $.41 * *$ \\
\hline Meta-cognitive & $-.54 * *$ & $.56 * *$ & $.72 * *$ & $.72 * *$ & $.47 * *$ & $.45^{* *}$ & $.57 * *$ \\
\hline Compensation & $-.36 * *$ & $.30 * *$ & $.51 * *$ & $.43 * *$ & $.20 * *$ & $.20 * *$ & $.31 * *$ \\
\hline Affective &.$-60 * *$ & $.79 * *$ & $.82 * *$ & $.93 * *$ & $.78 * *$ & $.75 * *$ & $.85^{* *}$ \\
\hline Social & $-.26 * *$ & $.51 * *$ & $.38 * *$ & $.42 * *$ & $.42 * *$ & $.44 * *$ & $.43 * *$ \\
\hline
\end{tabular}

$* *$ Correlation is significant at 0.01 level (2-tailed).

In a nutshell, Pearson product -moment Correlation was conducted to examine the relationship between types of motivation (Amotivation, Extrinsic motivation-external regulation, Extrinsic motivation- identified regulation, Extrinsic motivation- introjected regulation, Intrinsic motivation-accomplishment, Intrinsic motivation-knowledge, and Intrinsic motivation- stimulation) and use of strategies in language learning (Memory, Cognitive, Meta-cognitive, Compensation, Social, and Affective strategies). The results showed that the most common type of motivation was extrinsic motivation- identified and extrinsic motivation- introjected was the least frequent type among Iranian language learners.

Learners reported to use social, cognitive, and meta-cognitive strategies most frequently; and memory, compensation, and affective strategies least frequently. Based on the findings, significant correlation was found between motivation type and strategy use. It was found that both extrinsic motivation subscales and intrinsic motivation subscales were correlated positively and significantly with all six language learning strategies. However, amotivation demonstrated negative and significant correlation with all types of language learning strategies.

Finally, significant difference was found between male and female learners in terms of language learning strategies use. Female learners were found to be not only more motivated but also more language learning strategies users.

\section{DISCUSSION}

The purpose of the present study was to investigate the relationship between language learning strategies and type of motivation. It also aimed to examine the effect of gender on the choice of language learning strategies among Iranian EFL learners.

In the present study, students were found to be more extrinsically motivated rather than intrinsically motivated. It seemed that most of the students wanted to learn English for external purposes such as getting job, rewards, or satisfying expectations. These results were in congruence with previous studies such as (Chang, 2005; Chang \& Huang, 1999; Chung, 2000; Liao, 2000; Pong, 2002) that students were reported to be more extrinsically motivated.

It is worth mentioning that the means for two sub-scales of intrinsic motivation, namely knowledge $(\mathrm{M}=2.76)$ and accomplishment $(\mathrm{M}=2.77)$, were somewhat low in comparison with Amotivation $(\mathrm{M}=3.09)$ and two extrinsic motivation sub-scales, namely identifed motivation $(\mathrm{M}=3.29)$ and external motivation $(\mathrm{M}=3.23)$. It can indicate that students in this sample did not show strong enthusiasm for English learning. The phenomenon may be due to the environmental fact that English is viewed as foreign language in Iranian EFL context and it is not the immediate medium of communication among Iranian people. Some students may think that it is not necessary to learn English in an EFL context because they are provided with scanty opportunity to use English in their daily life. This result was consistent with previous studies (Cetinkaya, 2005; Chang, 2005; Alemi, Tajeddin, \& Mesbah, 2012).

By investigating the relationship between motivation types through Pearson product moment correlation analysis, it was found that there was a positive correlation among motivation types including, external motivation, introjected motivation, identified motivation, intrinsic motivation-knowledge, intrinsic motivation-accomplishment, and intrinsic motivation stimulation. However, amotivation showed negative correlation with all types of motivation. The findings can confirm the point that though extrinsic and intrinsic motivations are always viewed as opposite motivation, it is still possible for learners to learn English for both intrinsic and extrinsic purposes. According to Chang (2005), learners may learn English for obtaining instrumental goals, but they may still get a sense of fulfillment from the process of learning. 
With regard to language learning strategies, statistically significant differences were found between male and female learners in their overall strategy use. In the present study, female learners indicated significantly greater use of language learning strategies than male learners in three categories of SILL, namely cognitive strategies, meta-cognitive strategies, and social strategies. However, male learners revealed greater use of compensation strategy. The finding of gender differences is in accordance with previous research studies (Ehrman \& Oxford, 1989; Green \& Oxford, 1995; Kaylani, 1996; Noguchi, 1991; Nyikos, 1990; Oxford, 1993; Oxford \& Ehrman, 1993; Oxford \& Nyikos, 1989; Politzer, 1983; Willing, 1988; Yang, 1994). According to Oxford (1993), this finding can be attributed to female's social skills, stronger verbal skills, and greater conformity to academic and linguistic norms.

The results of current study with respect to the significant relationship between motivation and language learning lent support to the previous studies (Ames \& Archer, 1988; Bacon \& Finnemann, 1990; Fleming \& Wall, 1998; Chang \& Huang, 1999; McIntosh \& Noels, 2004). Based on the results of the present study it was shown that students with stronger motivation tend to use more language learning strategies than learners with less stronger motivation (Oxford, 1990; Oxford \& Nykos, 1989).

\section{CONCLUSION}

Broadly speaking, while some of the results of the present study are in agreement with the findings of previous research on strategy use (Green \& Oxford, 1995: O'Malley \& Chamot, 1990), the current study broadens the pattern of strategy more than previous studies. Like previous research (Khalil, 2005), the current results demonstrated that English students were totally aware of the utmost importance role of using learning strategies to the development of their language learning; social strategies were the most frequent kind of strategies among the students. Further, a similar result regarding the least frequent strategies, was obtained by Hong-Nam \& Leavell (2006), indicating that the least preferred strategies were affective and memory strategies. Thus, the use of social strategy and metacognitive strategy, the most frequent ones, should be incorporated in curriculum design, especially through the beginning stages of learning a second/foreign language, where accomplishing some type of declarative knowledge is critical in order to create "heightened understanding of the what and how of successful language learning" (Hong-Nam \& Leavell, 2006, p. 412).

Based on the findings of the study, it can be concluded that Iranian EFL learners were more extrinsically motivated and they tried to learn English for instrumental goal rather than for inner enjoyment. As to language learning strategies, the students appeared to use social strategy and meta-cognitive strategy most frequently. In other words, learners tend to communicate and make interaction with each other to and to make plan and evaluate their performance to facilitate their language learning process.

The relationship between type of motivation and language learning strategies were also investigated and it was found that both extrinsic and intrinsic subscales were correlated positively and significantly with all six language learning strategies. However, amotivation demonstrated negative and significant correlation with all six language learning strategies.

Gender was found to have influential effects on language learning strategies. Female students tended to use more language learning strategies in comparison with their male counterparts. Furthermore, significant difference was found between male and female students in terms of four language learning strategies, including cognitive, met-cognitive, social, and compensation strategies. Female students employed more cognitive, met-cognitive, social strategies while male students used more compensation strategy.

\section{REFERENCES}

[1] Alemi, M., Tajeddin, Z,. \& Mesbah. Z. (2012). Willingness to communicate: The roles of Motivation, Communication Anxiety, Linguistic self-confidence, and Attitude. Lambert Academic Publishing.

[2] Ames, C., \& Archer, G. (1987). Mothers' belief about the role of ability and effort in school learning. Journal of Educational Psychology, 18, 409-418.

[3] Archer, J. (1994). Achievement goals as measure of motivation in university students. Contemporary Educational Psychology 80, 3, 260-267.

[4] Bacon, S. M., \& Finnemann, M. D. (1990). A study of attitudes, motives, and strategies of foreign language students and their disposition to authentic oral and written input. The Modern Language Journal, 74, 459-470.

[5] Braten, I., \& Olaussen, B. S. (1998). The relationships between motivational beliefs and learning strategy use among Norwegian college students. Contemporary Educational Psychology, 23, 182-194.

[6] Cetinkaya, Y. B. (2005). Turkish college students' willingness to communicate in English as a foreign Language. Unpublished $\mathrm{PhD}$ Dissertation. Ohio State University.

[7] Chamot, A. U., \& Kupper, L. (1989).Learning strategies in foreign language instruction. Foreign Language Annals, 22 (1), 13 24.

[8] Chang, S. M., \& Huang, S. H. (1999). Taiwanese English learners' learning motivation and language learning strategies. Proceeding of the sixteenth conference of English teaching and learning in Republic of China (pp. 111-128).

[9] Chang, H. H. (2005). The relationship between extrinsic/intrinsic motivation and language learning strategies among college students of English in Taiwan. Unpublished Master Thesis. Ming Chuan University, China.

[10] Chang, C. Y., Liu, S. C., \& Lee, Y. N. (2007). A study of language learning strategies used by college EFL learners in Taiwan. Language Learning, 3, 235-262. 
[11] Deci, E.L., \& Ryan, R.M. (2000). The "what" and the "why" of goal pursuits: Human needs and the self-determination of behavior. Psychological Inquiry, 11, 227-268.

[12] Dornyei, Z. (2000). Motivation in second and foreign language learning. Language Teaching, 31, 117-135.

[13] Ehrman, M., \& Oxford, R. (1989). Effects of sex differences, career choice and psychological type on adult language learning strategies. The Modern Language Journal, 73, 1-13.

[14] Gardner, R. C. (1985). Social psychology and second language learning: The roles of attitudes and motivation. London: Edward Arnold.

[15] Green, J. M., \& Oxford, R. (1995). A closer look at learning strategies, L2 proficiency, and gender. TESOL Quarterly, 29 (2), 261-297.

[16] Grenfell, M., \& Harris, V. (1999). Modern languages and learning strategies in theory and practice. London: Routledge.

[17] Hon-Nam, K. \& Leavell, A. (2006). Language learning strategy use of ESL students in an intensive English learning context. System, 34, 399-415.

[18] Kaylani, C. (1996). The influence of gender and motivation on EFL learning strategy use in Jordan. In R. Oxford (Ed.). Language learning strategies around the world: Cross-cultural perspectives (pp. 75-88). Honolulu: University of Hawai'I, Second Language Teaching \& Curriculum Center.

[19] Khalil, A. (2005). Assessment of language learning strategies used by Palestinian EFL learners. Foreign Language Annals, $38(1), 108-119$

[20] Lee, K.O. (2003). The relationship of school year, sex and proficiency on the use of learning strategies in learning English of Korean junior high school students. Asian EFL Journal, 1, 1-36.

[21] Liao, Y. F. (2000). Taiwanese secondary school students' motivation and language learning strategies. Language Teaching, 3 , 155-183.

[22] Littlewood, W. (1996). Autonomy: An autonomy and framework, System, 24, 427-435.

[23] McIntosh, C. N., \& Noels, K. A. (2004). Self-determined motivation for language learning: The role of need for cognition and language learning strategies. Online Journal, 9 (2), 28.

[24] Noels, K. A., Pelletier. L. G., Clement. R., \& Vallerand. R. J. (2000). Why are you learning a second language? Motivational orientations and self-determination theory. Language Learning, 50(1), 57-85.

[25] Noguchi, T. (1991). Review of language learning strategy: Research and its implications. Unpublished bachelor's thesis, Tottori University, Tottori, Japan, 1991.

[26] O’Malley, J. M., Chamot, A. U., Stewner-Manzanares, G., Russo, R., \& Küpper, L. (1985) Learning strategy applications with students of English as a second language. TESOL Quarterly, 19 (3), 557-584.

[27] Oxford, R. L. (1989). Use of language learning strategies: A synthesis of studies with implications for strategy training. System, $17(2), 235-247$.

[28] Oxford, R. L. (1990). Language learning strategies: What every teacher should know. Boston: Heinle and Heinle.

[29] Oxford, R. (1993). Research on second language learning strategies. Annual Review of Applied Linguistics, 13, 175-187.

[30] Oxford, R., \& Nyikos, M. (1989). Variables affecting choice of language learning strategies by university students. The Modern Language Journal, 73, 291-300.

[31] Pintrich, P. R., \& Garcia, T. (1991). Student goal orientation and self-regulation. In Maeher, P. R. Pintrich. Advances in motivation and achievement: Goals and self-regulatory processes (PP. 371-402). Greenwich, CT: JAI Press.

[32] Politzer, R. (1983). An exploratory study of self-reported language learning behaviors and their relation to achievement. Second Language Acquisition, 6, 54-65.

[33] Pong, G. (2002). EFL motivation and strategy use among Taiwanese senior high school learners. Unpublished Master thesis. National Taiwan University of education. Taiwan: Taipei.

[34] Ramasay, R.M.G. (1980). Language learning approach styles of adult multilingual and successful language learners. Annals of the New York Academy of Sciences, 345, 73-96.

[35] Reiss, M. A. (1983). Helping the unsuccessful language learner. Canadian Modern Language Review, 39 (2), $256-266$.

[36] Rubin, J. (1975). What the "good language learner" can teach us. TESOL Quarterly, 9, 41-51.

[37] Stern, H. H. (1975). What can we learn from the good language learner? Canadian Modern Language Review, 31, 304-18.

[38] Tabanlioglu, S. (2003). The relationship between learning styles and language learning strategies of pre-intermediate EAP students. Unpublished Master Thesis. Middle East Technical University.

[39] Vallerand, R.J., Pelletier, L.G., Blais, M.R., Brière, N.M., Sénécal, C. \& Vallières, E.F. (1992). The Academic Motivation Scale: A measure of intrinsic, extrinsic and amotivation in education. Educational and Psychological Measurement, 52, 10031017.

[40] Willing, K. (1988). Learning styles in adult immigrant education. Research Series. Australia: National Curriculum Research Center: Adult Migrant Education Programme. Taipei: The Crane Publishing Co.

[41] Yang, N. D. (1994). A study of factors affecting college EFL students' use of learning strategies. Papers of the eleventh conference on English teaching and learning in the Republic of China (pp.53-82). Taipei, Taiwan: The Crane Publishing Co.

Zeinab Moradi Khazaie was born in Kermanshah, Iran in 1986. She got her B.A. degree in English Language and Literature in 2009 from Razi University, Kermanshah, Iran .In 2012 she earned her M.A. degree in Teaching English as a Foreign Language (TEFL) from University of Isfahan, Isfahan, Iran.

She has been English Language INSTRUCTOR at several language centers for seven years, and she is Language instructor at Islamic Azad University of Kermanshah Iran nowShe had publishe and an article in international journal entitled Moradi Khazaie. Z., Moin Zadeh. A,, Ketabi. S. (2012) Willingness to communicate among Iranian EFL learners: The effect of different class size. Canadian Center of Science and Education. 5(11) 1-7. Her main area of interest is Educational Studies, SLA, Social studies and Research. 
Zahra Mesbah was born in Iran in 1986. She earned her B.A. degree in English Language and Literature in 2009 from Razi University, Kermanshah, Iran. She got her M.A. degree in Teaching English as a Foreign Language (TEFL) in 2012 from Sharif University of Technology, Tehran, Iran.

She has been an English language INSTRUCTOR at different language centers for over five years. She is now R \& D Staff and English Expert at Danesh Gostar KooheNoor institute, Tehran, Iran. She has published a book (Alemi, M., Tajeddin, Z,. \& Mesbah. Z. (2012). Willingness to communicate: The roles of Motivation, Communication Anxiety, Linguistic self-confidence, and Attitude. Lambert Academic Publishing), an articles in an international journal (Alemi, M., \& Mesbah, Z. (2012). Textbook evaluation based on the ACTFL standards: The case of Top Notch series. Iranian EFL Journal, 9(1), 162-170), and given presentation at two international conferences (Textbook Evaluation based on the ACTFL standards: Top Notch series. Paper presented at MATSDA/University of Limerick Conference, Applied Linguistics and Materials Development. Ireland) and (Willingness to Communicate in English: Impacts of learner variables. Paper presented at 5th international Conference of Education, Research, and Innovation. Madrid, Spain). Her main areas of interest lie in second language learning and teaching, syllabus design, ESP, and Educational studies. 